\title{
Assessment of Characterization of Leachate Generated using Leachate Generated Model
}

\author{
Kamde Shivanand, Ghosh P. K., Gupta M. K.
}

\begin{abstract}
There are many approaches which have been used to assess the ground water and surface water contamination. The land disposal of municipal waste is potential cause of groundwater contamination unscientifically managed dumping yards are prone to groundwater contamination because of leachate production. The leaching behaviour of a waste can be assessed either by the experimental determination of the characteristics of leachate generated or through mathematical modeling. A pilot study was conducted to assess the characterization of leachate generating using Leachate Generated Model (LGM). In present study the model is used to study the effect of gomutra and enzymes on the municipal solid waste and the leachate quality. The result indicated that the colour of leachate generated in study area was found to be oxygenated and has organic compound which resulted in increased permeability. The results reveal that the use of gomutra (15\%) mixed with $M S W$, was a good indication that organic matters in leachate are readily biodegradable in mature land fill, where as $10 \%$ gomutra used in MSW, showed that $(B O D / C O D=0.64)$ leachate had high biodegradability through anaerobic phase. This stimulator showed better result than enzymes used and is also helpful to prevent containing of waste water tube wells and bore holes affected from leachate generated.
\end{abstract}

Keywords: Municipal Solid Waste (MSW), Leachate Generated Model (LGM), Leachate Characterization, Biological Oxygen Demand (COD), Land Wasted Water Samples.

\section{INTRODUCTION}

The most common disposal option for MSW practised currently in many countries is either uncontrolled dumping on land1 or open burning. ${ }^{2,3,4,5,6,7,8}$ The liquid containing innumerable organic and inorganic compounds is called as leachate. It is a strong reducing liquid formed under methanogenic conditions and on coming into contact with aquifer materials has the ability to reduce sorbed heavy metals in the aquifer matrix. ${ }^{9}$ The influence of leachate from each type of landfill depended on many factors such as waste composition, leachate characteristics, precipitation and the

Revised Manuscript Received on August 15, 2020.

* Correspondence Author

Kamde Shivanand*, Research Scholar, Bhilai Institute of Technology, Durg, Chhattisgarh, India.

Ghosh P. K., Principal, Krishna Engineering College, Bhilai, Chhattisgarh, India.

Gupta M. K., Head of Department, Department of Civil, Bhilai Institute of Technology, Durg, Chhattisgarh, India.

(C) The Authors. Published by Blue Eyes Intelligence Engineering and Sciences Publication (BEIESP). This is an open access article under the CC BY-NC-ND license (http://creativecommons.org/licenses/by-nc-nd/4.0/) age of the landfill. Since leachates are one of the most potential sources of ground water pollution, monitoring heavy metal content viz. Copper $(\mathrm{Cu})$, Lead $(\mathrm{Pb})$, Cadium $(\mathrm{Cd})$, Manganese (Mn), etc. is dump site can facilitate to recommended measures. ${ }^{10}$

Unscientifically managed dumping yards are prone to groundwater contamination because of leachate production. ${ }^{11}$ It is very essential that the volume and its effect of leachate generated be kept to a minimum and also ensure that the ingress of groundwater and surface water is minimised and controlled. In this regard the researcher has developed a leachate generated model to characterization of leachate generated from the landfill of the study area; using gomutra as a stimulator. The leaching behaviour of a municipal solid waste can be experimentally acquired through various leaching tests viz. static and dynamic test used for different purposes. To estimate the environmental threats of solid materials, leaching tests to determine characterization of MSW and leachate quality were done in the laboratory. In this context, waste flow percolation test conducted by Brit Marie Svensson $^{12}$ and Wring column test performed by Franscesca Polalo $^{13}$ were referred in this study. Brit Marie Sevensson were focused on Liquid Solid Ratio (L/S Ratio) presented the leachate concentration where as Franscesca Polalo had developed his model to define behaviours of concentration of leachate using risk analysis. The present study deals with generation of leachate in the model, developed; using MSW of the area studied, mixed with gomutra as a stimulator and were performed leachate quality using laboratory analysis.

\section{MATERIALS AND METHODS}

\subsection{Study Area}

The study area i.e. Durg is one of the most important education and commercial centre of Chhattisgarh state, having population 2,68,806 (As per Census 2011). It generates 80 tonne of MSW per day means the generation rate is about 300 gram per capita per day. Solid Waste Management in Durg is mainly based on the disposal of waste through the single operational landfills located at Potiyakala village situated about 2.5 kilometres away from Potiya Square.

\subsection{Leachate Generation Methodology}

For the generation of leachates, municipal solid waste sample of study area were collected in the winter, summer and rainy season. Now leachate has been generated from a landfill prototype model designed by the researcher.

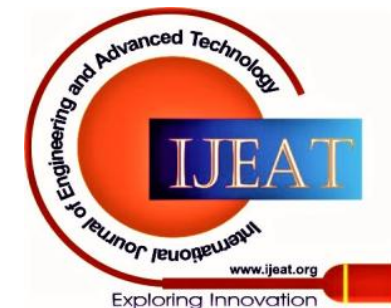




\section{Assessment of Characterization of Leachate Generated using Leachate Generated Model}

The procedure adopted here is similar to actual procedure adopted for sanitary land filling however the ratio is kept 1 : 10. To simulate a sanitary landfill having a maximum possible depth of $20 \mathrm{~m}$. The bottom of acrylic transparent hollow tube having dimension of $200 \mathrm{~mm}$ diameter and $2.25 \mathrm{~m}$ length was covered with a $5 \mathrm{~mm}$ sieve size mesh and a cotton cloth. It was then supported with steel stand vertically in such a way that the bottom of tube just touches the ground. The MSW is then filled for $5 \mathrm{~cm}$ and well compacted, this was repeated until the depth becomes $15 \mathrm{cms}$ and then good earth / soil layer was spread and compacted. This procedure was repeated until the tube was filled for $1.95 \mathrm{~m}$ and finally top layer was $6 \mathrm{~cm}$ depth good earth. To simulate natural condition of landfill a water spray system was used using a portable rainfall stimulator which can be adjusted to stimulate a light rain (10 mm / hour) to heavy rain (100 mm / hour). The leachate is then developed using deionized water in a static exposure and rainfall stimulation using water flow metre (WFM) @ 2 - 20 ml per minutes, using $0 \%, 5 \%, 10 \%$ and $15 \%$ of gomutra in such a models filled with MSW. Continuous monitoring has also been done for 30 days.

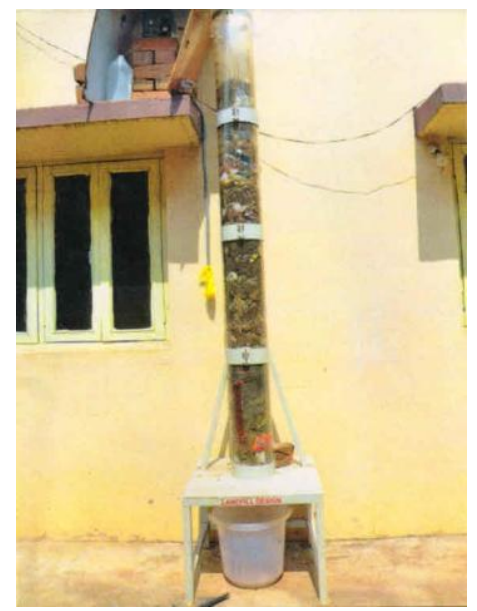

Fig. 1: Landfill Design Model

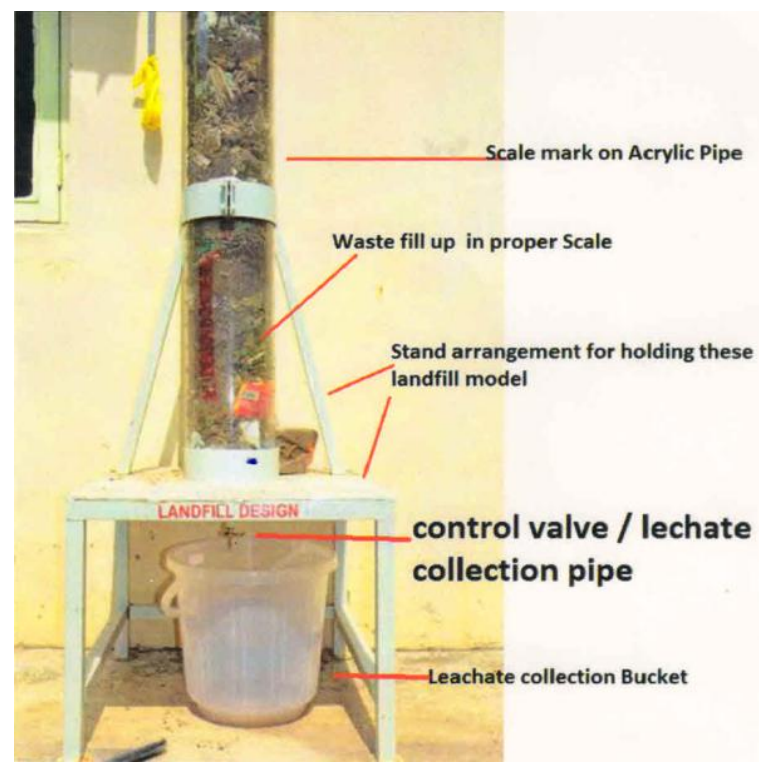

Fig. 2: Details of Landfill Design Model showing various elements

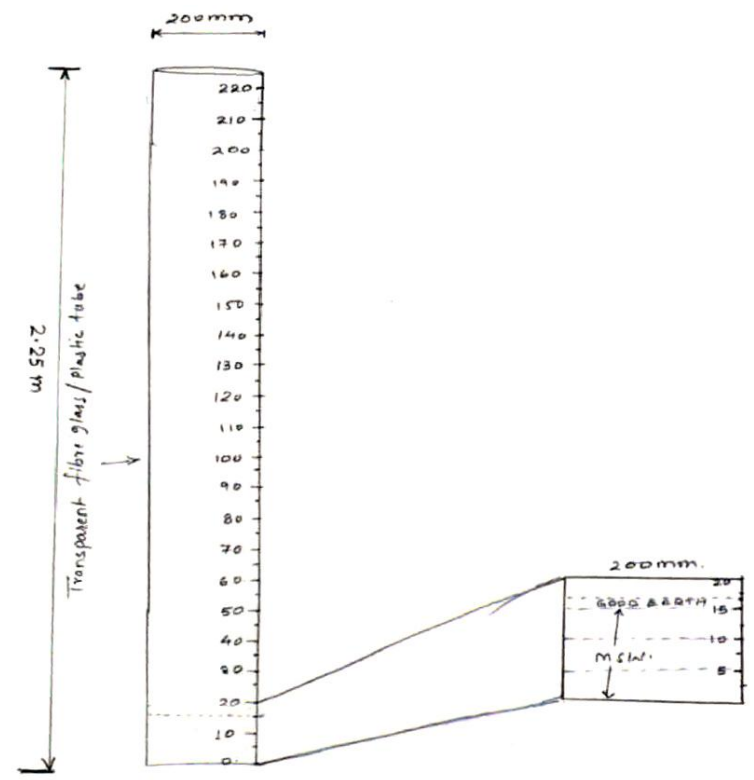

Fig. 3: Schematic diagram of Leachate Generation Model

In this study a study of leachate characteristics before and after treatment using gomutra has been done, using 21 parameters and results are tabulated.

Table 1: Leachate Characteristics before and after Treatment using Gomutra

\begin{tabular}{|c|c|c|c|c|c|c|}
\hline $\begin{array}{l}\text { Sr. } \\
\text { No. }\end{array}$ & Characteristic & $\begin{array}{c}\text { Outlet @ } \\
\text { Pilot Plant }\end{array}$ & $\begin{array}{l}\text { Outlet @ Pilot } \\
\text { Plant solid waste } \\
\text { mix with 5\% } \\
\text { Goumutra }\end{array}$ & $\begin{array}{l}\text { Outlet@ Pilot } \\
\text { Plant solid waste } \\
\text { mix with } 10 \% \\
\text { Goumutra }\end{array}$ & $\begin{array}{c}\text { Outlet@ Pilot } \\
\text { Plant solid waste } \\
\text { mix with } 15 \% \\
\text { Goumutra }\end{array}$ & $\begin{array}{c}\text { Outlet@ Pilot } \\
\text { Plant solid waste } \\
\text { mix with } \\
\text { Enzymes }\end{array}$ \\
\hline 1 & Colour & 10 & 28 & 28 & 28 & 28 \\
\hline 2 & $\mathrm{pH}$ & 8 & 8.2 & 8.3 & 8.7 & 9.1 \\
\hline 3 & Suspended Solids & 24 & 35 & 36 & 67 & 152 \\
\hline 4 & Chloride (as Cl) & 550 & 90 & 120 & 170 & 1800 \\
\hline 5 & $\begin{array}{c}\text { Total Hardness } \\
\text { (as } \mathrm{CaCO}_{3} \text { ) }\end{array}$ & 370 & 250 & 340 & 400 & 1740 \\
\hline 6 & Calcium (as Ca) & 88.2 & 70 & 73.7 & 78.9 & 320.6 \\
\hline 7 & Magnesium (as Mg) & 36.5 & 36 & 37.9 & 38 & 228.4 \\
\hline \multicolumn{3}{|c|}{$\begin{array}{l}\text { Retrieval Number: F1537089620/2020@BEIESP } \\
\text { DOI: 10.35940/ijeat.F1537.089620 } \\
\text { Journal Website: } \underline{\text { www.ijeat.org }}\end{array}$} & \multicolumn{3}{|c|}{$\begin{array}{l}\text { Published By: } \\
\text { Blue Eyes Intelligence Engineering } \\
\text { and Sciences Publication } \\
\text { (C) Copyright: All rights reserved. }\end{array}$} & \\
\hline
\end{tabular}




\begin{tabular}{|c|c|c|c|c|c|c|}
\hline $\begin{array}{l}\text { Sr. } \\
\text { No. }\end{array}$ & Characteristic & $\begin{array}{c}\text { Outlet @ } \\
\text { Pilot Plant }\end{array}$ & $\begin{array}{c}\text { Outlet @ Pilot } \\
\text { Plant solid waste } \\
\text { mix with 5\% } \\
\text { Goumutra }\end{array}$ & $\begin{array}{c}\text { Outlet @ Pilot } \\
\text { Plant solid waste } \\
\text { mix with } 10 \% \\
\text { Goumutra }\end{array}$ & $\begin{array}{c}\text { Outlet @ Pilot } \\
\text { Plant solid waste } \\
\text { mix with } 15 \% \\
\text { Goumutra }\end{array}$ & $\begin{array}{c}\text { Outlet @ Pilot } \\
\text { Plant solid waste } \\
\text { mix with } \\
\text { Enzymes }\end{array}$ \\
\hline 8 & Sodium & 380 & 70 & 76 & 90 & 1120 \\
\hline 9 & Acidity & 20 & Nil & Nil & Nil & Nil \\
\hline 10 & Kjeldahl Nitrogen & 24.1 & 8.1 & 8.4 & 8.9 & 14 \\
\hline 11 & Total Phosphorous & 0.11 & 0.32 & 0.34 & 0.35 & 0.86 \\
\hline 12 & BOD & 38 & 20 & 22 & 25 & 58 \\
\hline 13 & COD & 170 & 40 & 50 & 55 & 130 \\
\hline 14 & Iron (as Fe) & 0.8 & 0.6 & 0.8 & 0.7 & 1.1 \\
\hline 15 & Oil and Grease & 0 & 0 & 2 & 3 & 4 \\
\hline 16 & Total Arsenic & 0.01 & N.D. & N.D. & N.D. & N.D. \\
\hline 17 & Copper (as Cu) & 0.06 & 0.05 & 0.05 & 0.05 & 0.09 \\
\hline 18 & Cadmium (as Cd) & $<0.001$ & $<0.001$ & $<0.001$ & $<0.001$ & $<0.001$ \\
\hline 19 & Lead (as Pb) & 0.001 & 0.03 & 0.03 & 0.03 & 0.06 \\
\hline 20 & $\begin{array}{l}\text { Total Chromium } \\
\text { (as Cr) }\end{array}$ & $<0.05$ & $<0.03$ & $<0.03$ & $<0.03$ & $<0.03$ \\
\hline 21 & Zinc (as Zn) & 0.16 & 0.45 & 0.54 & 0.67 & 0.23 \\
\hline
\end{tabular}

results are tabulated.

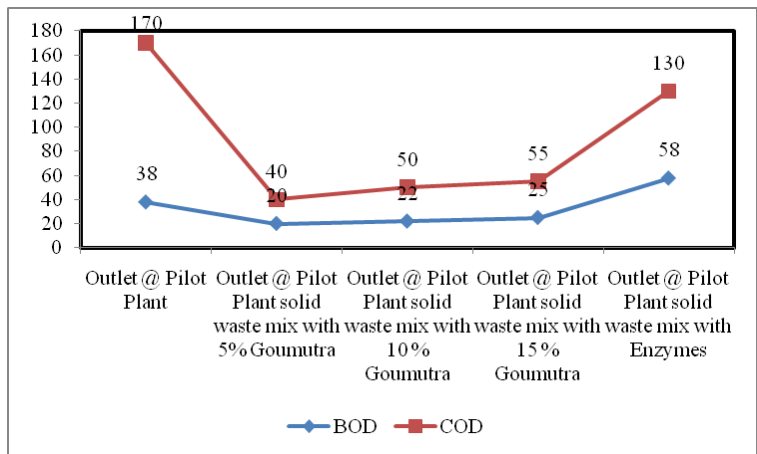

Fig. 4: Graphical representation of Leachate Characteristics before and after Treatment

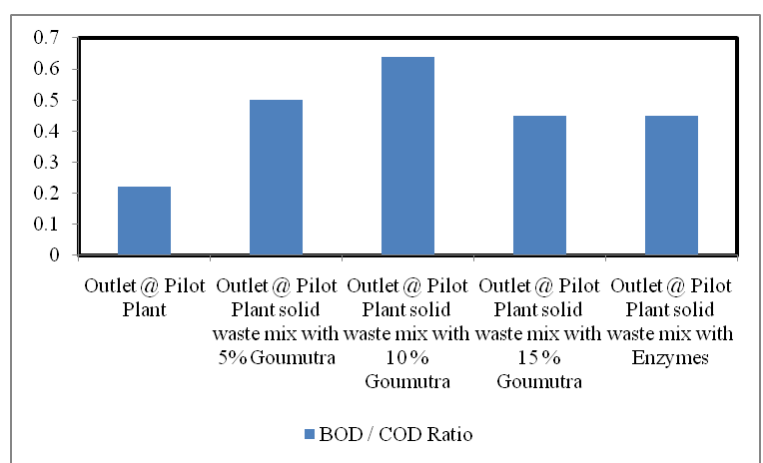

Fig. 5: Bar Chart showing BOD / COD ratio before and after Treatment

The ratio of BOD to COD is a commonly used indicator of waste decomposition and can also guide the leachate treatment process and establish the grounds for the assessment of the environmental risk of leachate. ${ }^{14,15,16}$

Since the landfill site was not equipped with a leachate collecting system, therefore the leachate from the base of landfill was collected randomly from three different locations at 10 metre lateral spacing from the boundary of landfill for the study purpose. Sample collection was done as per the IS 3025 (Part-1): 1987. The samples were collected directly from the anger. In this study collection of tube well water samples have done from 3 tube wells viz. $\mathrm{TW}_{1}, \mathrm{TW}_{2}$ and $\mathrm{TW}_{3}$ and analysed for 15 characteristics. Similarly, waste water samples from 12 bore holes of depth of $10 \mathrm{~m}, 20 \mathrm{~m}$ and $30 \mathrm{~m}$, were collected and analysed for total 21 parameters and

Retrieval Number: F1537089620/2020@BEIESP

DOI: 10.35940/ijeat.F1537.089620

Journal Website: www.ijeat.org

Table 2: Characteristics of Tube Well Samples of near landfill site

\begin{tabular}{|c|l|c|c|c|}
\hline $\begin{array}{c}\text { Sr. } \\
\text { No. }\end{array}$ & \multicolumn{1}{|c|}{ Characteristic } & $\begin{array}{c}\text { Tube } \\
\text { Well-I }\end{array}$ & $\begin{array}{c}\text { Tube } \\
\text { Well-II }\end{array}$ & $\begin{array}{c}\text { Tube } \\
\text { Well-III }\end{array}$ \\
\hline 1 & $\mathrm{pH}$ & 8.3 & 8.2 & 8.2 \\
\hline 2 & Total Solids & 376 & 375 & 375 \\
\hline 3 & $\begin{array}{l}\text { Total Dissolved } \\
\text { Solids }\end{array}$ & 369 & 360 & 364 \\
\hline 4 & Suspended Solids & 12 & 15 & 10 \\
\hline 5 & $\begin{array}{l}\text { Total Hardness (as } \\
\text { CaCO }\end{array}$ & 274 & 274 & 272 \\
\hline 6 & Calcium (as Ca) & 76 & 78 & 76.2 \\
\hline 7 & Magnesium (as Mg) & 20 & 19.3 & 19.6 \\
\hline 8 & Iron (as Fe) & 0.1 & 0.1 & 0.1 \\
\hline 9 & Manganese (as Mn) & 0.03 & 0.03 & 0.03 \\
\hline 10 & Total Arsenic & 0.01 & 0.01 & 0.01 \\
\hline 11 & Copper (as Cu) & 0.15 & 0.15 & 0.15 \\
\hline 12 & Cadmium (as Cd) & 0.05 & 0.05 & 0.05 \\
\hline 13 & Lead (as Pb) & 0.001 & 0.001 & 0.001 \\
\hline 14 & $\begin{array}{l}\text { Total Chromium (as } \\
\text { Cr) }\end{array}$ & 0.03 & 0.03 & 0.03 \\
\hline 15 & Zinc (as Zn) & 0.55 & 0.54 & 0.55 \\
\hline
\end{tabular}


Assessment of Characterization of Leachate Generated using Leachate Generated Model

Table 3: Characteristics of Leachate Samples (Waste Water Samples from Bore Holes)

\begin{tabular}{|c|c|c|c|c|c|c|c|c|c|c|c|c|c|}
\hline \multirow[b]{2}{*}{$\begin{array}{l}\text { Sr. } \\
\text { No. }\end{array}$} & \multirow[b]{2}{*}{ Characteristics } & \multicolumn{4}{|c|}{ BH1 (@ 10 m) } & \multicolumn{4}{|c|}{ BH2 (@ 20 m) } & \multicolumn{4}{|c|}{ BH3 (@ 30 m) } \\
\hline & & BH1A & BH1B & BH1C & BH1D & BH2A & ВH2B & BH2C & $\begin{array}{c}\text { BH2 } \\
\text { D }\end{array}$ & ВНЗА & $\begin{array}{c}\text { BH3 } \\
\text { B }\end{array}$ & ВНЗС & $\begin{array}{c}\text { BH3 } \\
\text { D }\end{array}$ \\
\hline 1 & Colour & 6.2 & 7.4 & 9.7 & 6.8 & 6.5 & 7 & 7.9 & 6 & 6.9 & 7.1 & 7.6 & 6 \\
\hline 2 & $\mathrm{pH}$ & 7.7 & 7 & 7.6 & 7.5 & 7.7 & 7.2 & 7.5 & 8 & 7 & 7.9 & 7.6 & 7.5 \\
\hline 3 & $\begin{array}{l}\text { Suspended } \\
\text { Solids }\end{array}$ & 66 & 56 & 66 & 66 & 60 & 61 & 62 & 62.6 & 69 & 62 & 65 & 66 \\
\hline 4 & Chloride (as Cl) & 620 & 617 & 620 & 200 & 620 & 604 & 619 & 210 & 623 & 613 & 618 & 205 \\
\hline 5 & $\begin{array}{l}\text { Total Hardness } \\
\text { (as } \mathrm{CaCO}_{3} \text { ) }\end{array}$ & 900 & 870 & 899 & 1000 & 700 & 603 & 604 & 630 & 890 & 910 & 892 & 1000 \\
\hline 6 & Calcium (as Ca) & 208.4 & 200.3 & 209.1 & 189 & 200 & 178 & 189 & 190 & 218.4 & 208.4 & 218.4 & 189 \\
\hline 7 & $\begin{array}{l}\text { Magnesium } \\
\text { (as Mg) }\end{array}$ & 92.3 & 90.9 & 90.3 & 120 & 80.8 & 92 & 96 & 123 & 92.3 & 93.8 & 91.9 & 120 \\
\hline 8 & Sodium & 430 & 412 & 427 & 560 & 421 & 430 & 432 & 545 & 434 & 421 & 438 & 560 \\
\hline 9 & Acidity & 68 & 60 & 56 & 76 & 67 & 76 & 89 & 79 & 68 & 65 & 69 & 76 \\
\hline 10 & $\begin{array}{l}\text { Kjeldahl } \\
\text { Nitrogen }\end{array}$ & 82.9 & 80 & 80.1 & 170 & 81.9 & 82.9 & 87.9 & 178 & 80.9 & 84.6 & 87 & 170 \\
\hline 11 & $\begin{array}{c}\text { Total } \\
\text { Phosphorous }\end{array}$ & 0.28 & 0.21 & 0.28 & 80 & 0.26 & 0.27 & 0.29 & 89 & 0.21 & 0.28 & 0.29 & 80 \\
\hline 12 & BOD & 180 & 176 & 167 & 210 & 178 & 180 & 167 & 210 & 178 & 179 & 175 & 210 \\
\hline 13 & COD & 430 & 380 & 403 & 600 & 410 & 413 & 421 & 600 & 421 & 434 & 450 & 600 \\
\hline 14 & Iron (as Fe) & 1.2 & 1.1 & 1.09 & 2 & 1.24 & 1.2 & 1.23 & 2.1 & 2.1 & 1.8 & 1.3 & 2 \\
\hline 15 & Oil and Grease & 0.43 & 0.4 & 0.41 & 0.7 & 0.41 & 0.45 & 0.41 & 0.8 & 0.41 & 0.43 & 0.49 & 0.7 \\
\hline 16 & Total Arsenic & 0.03 & 0.01 & 0.02 & 0.023 & 0.031 & 0.012 & 0.03 & 0.021 & 0.03 & 0.021 & 0.029 & 0.023 \\
\hline 17 & Copper (as Cu) & 0.16 & 0.12 & 0.16 & 0.34 & 0.15 & 0.17 & 0.19 & 0.38 & 0.21 & 0.16 & 0.18 & 0.34 \\
\hline 18 & $\begin{array}{l}\text { Cadmium } \\
\text { (as Cd) }\end{array}$ & $\begin{array}{c}0.001 \\
5\end{array}$ & 0.001 & $\begin{array}{c}0.001 \\
5\end{array}$ & $\begin{array}{c}0.002 \\
3\end{array}$ & $\begin{array}{c}0.001 \\
5\end{array}$ & $\begin{array}{c}0.001 \\
5\end{array}$ & $\begin{array}{c}0.001 \\
5\end{array}$ & 0.002 & $\begin{array}{c}0.001 \\
5\end{array}$ & 0.001 & $\begin{array}{c}0.001 \\
9\end{array}$ & 0.002 \\
\hline 19 & Lead (as Pb) & $\begin{array}{c}0.001 \\
1 \\
\end{array}$ & $\begin{array}{c}0.001 \\
4 \\
\end{array}$ & $\begin{array}{c}0.001 \\
3 \\
\end{array}$ & $\begin{array}{c}0.001 \\
9 \\
\end{array}$ & $\begin{array}{c}0.001 \\
1 \\
\end{array}$ & $\begin{array}{c}0.001 \\
2 \\
\end{array}$ & $\begin{array}{c}0.001 \\
1 \\
\end{array}$ & 0.002 & 0.002 & 0.001 & $\begin{array}{c}0.001 \\
5 \\
\end{array}$ & 0.002 \\
\hline 20 & $\begin{array}{c}\text { Total } \\
\text { Chromium } \\
\text { (as Cr) }\end{array}$ & 0.09 & 0.08 & 0.07 & 0.018 & 0.09 & 0.07 & 0.06 & 0.018 & 0.01 & 0.03 & 0.021 & 0.018 \\
\hline 21 & Zinc (as Zn) & 0.26 & 0.2 & 0.21 & 0.43 & 0.23 & 0.27 & 0.36 & 0.43 & 0.21 & 0.22 & 0.24 & 0.43 \\
\hline
\end{tabular}

\section{RESULTS AND DISCUSSION}

In this study the colour of leachate generated was observed and found to be dark brown indicating that leachate becomes oxygenated and have hurmic substance i.e., organic compounds which resulted that increased in permeability. The result of ratio of $\mathrm{BOD} / \mathrm{COD}(=0.22)$ showed that the leachate samples, collected from the landfill site with the age of more than 5 years. The concentration of $\mathrm{pH}$ value of leachate generated indicated that the nature of leachate is slightly alkaline; which was expected as the landfill is an old one. The soluble ions - concentration of sodium, calcium and magnesium is found to be within limits. However the presence of sodium are not much affected by microbiological activities within the land fill site but indicated about vegetable residues in the domestic waste.

The concentration of chlorides in the leachate generated at the land fill site showed the presence of inert (20.4\%) in the MSW of this area, which indicate towards the availability of non biodegradable compounds (i.e., plastic and rubber). The results reveal that the MSW with $15 \%$ gomutra was a good indication that organic matters in the leachate are readily biodegradable in mature land fill, where as $10 \%$ gomutra used in MSW showed that $(\mathrm{BOD} / \mathrm{COD}=0.64)$ leachate had high biodegradability through anaerobic phase. The stimulator used i.e., gomutra showed better result than the enzymes used and is also helpful to prevent contamination of wastewater of tube wells and bore holes affected from leachate generated at the landfill of the study area. Due to presence of inorganic materials in the tube well water samples become hard (total hardness as $\mathrm{CaCO}_{3}$ was found to be 273.33 (average), exceeded the permissible limit i.e., 200) which may not be domestic purpose. Similarly the results showed that the level of contamination of bore hole water, with respect to the value of $\mathrm{pH}$, total dissolved solids, calcium, copper, iron, cadium and zinc were exceeded the desirable limit as recommended by IS 10500 : 2012 for drinking purpose and hence may not be used for drinking purpose. But due to high concentration of $\mathrm{CaCO}_{3}$ present in $\mathrm{BH} 3 \mathrm{D}$ and $\mathrm{BH} 2 \mathrm{~A}$ of the study area, the water sample may be used for agricultural purpose.

\section{CONCLUSION}

In this study it has concluded that the poorly maintained unengineered landfill sites are prone to groundwater contamination because of leachate generated. The researcher has also enlighted the effect of gomutra used as a indicator provided better result than the enzyme used. Based on the facts and findings following conclusions have been drawn.

Published By:

Blue Eyes Intelligence Engineering and Sciences Publication

(C) Copyright: All rights reserved.

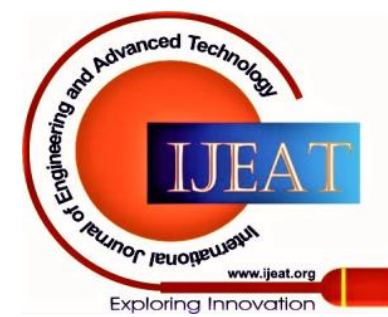


1. The colour of leachate generated showed that it becomes oxygenated and has organic compounds which also resulted in increased permeability.

2. The ratio of BOD / COD of leachate was found to be 0.22 clearly exhibited that the age of landfill which was more than 5 years. This was also proved that the 'alkaline leachate' generated at the landfill.

3. The concentration of chlorides in the leachate showed the presence of inert (20.4\%) which indicate towards the availability of non biodegradable waste containing plastics and rubber at the landfill site. On the other hand there is domestic waste at the landfill site.

4. The results showed that the tube well water samples polluted and affected from the leachate generated due to presence of inorganic material in the tube well water samples become hard which is not a health hazards and hence not suitable for domestic purpose. Similarly the results exhibited that the level of contamination of bore holes water samples was very high and hence not be used for drinking purpose, also dangerous to human health.

5. The study reveals that the result of combination of MSW and $10-15 \%$ of gomutra is effective organic treatment solution. This stimulator has also provided better result as compared to enzymes used and is also helpful to prevent contamination of wastewater of tube wells and bore holes affected from leachate generated. This stimulator is widely available at an affordable cost.

\section{REFERENCES}

1. Ramchandra, T.V., "Management of Municipal Solid Waste", Environmental Engineering Series, 2009, Teri Press, New Delhi, pp. 84.

2. Christine Wiedinmyer et al., "Global Emission and Trace Gases, Particular matter and Hazardous Air Pollutants from open burning of Dump waste", Env. Scie. and Tech., 2014.

3. Lisa W. Foderaro, "In a debate over trash burning. Its Rural traditional vs Health", New York Times, March 7, 2005.

4. Hoorn weals and Bhada - Jatu, pp. 87-88.

5. Brian K. Gullet et al., "PCD / F \& PBDE crises from open burning of a Residential Waste Dump", Engineering Science and Technology, 2010, pp. 398.

6. Bunrith Seng. et al., "MSW in Phnom Penh, capital city of Combodias", Waste Management and Research, 29 (5), 2010, pp. 495.

7. Enri Damanhuri et al., "Evolution of MSW flow in the Bandung metropolitan area, Indonesian", Journal of Material Cycles and Waste Management, 2009, pp. 272.

8. Nag Rajan Rao Kumar, Thinumalaisamy Subarmani, Lakshumanan Elangu, "Impact of leachate on ground water pollution due to non engineered MSW land fill sites of Erode city, Tamil Nadu, India”, Iranian J. Environ. Health Science Engineering, 9: 2012, pp. 8.

9. MoEF, "Municipal Solid Waste Management and Handling Rules", Ministry of Environment and Forests, Government of India, 2000.

10. Esakku S., Karthikeyan O.P., Joseph K. et al., "Seasonal variations in leachate characteristics from Municipal Solid Waste Dump sites in India and Sri Lanka", International Conference on Sustainable Solid Waste Management, 2007, pp. 341-347.

11. Pillai Sruiti, Anju Eizbath Peter, Sunil B.M. and Shriharis, "Soil Pollution near a Municipal solid waste disposal site in India", Biological, Civil and Environment Engineering, Dubai (UAE), 2014, pp. 148.

12. Brice Marie Svenssion, "Methodology for evolution of Hazards from solid waste and landfill generated leachate", Kristianstud University, Sweden, 2008, pp. 428.

13. Francesca Polalo, "Use of leachate tests to characterize land fill leachates in the long term period application in Risk Analysis Thesis", Kristanstad University, Swedan, 2012, pp. 17, 29, 30 and 31.

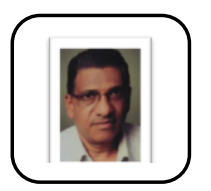

\section{AUTHORS PROFILE}

Shivanand Kamde was born in Bilaspur, Chhattisgarh, India and he graduated in Civil Engineering from Pt. Ravishankar Shukla University, Raipur in 1984. He then received $M$. The (Ed.) Post Graduate Degree from Barkatullah University, Bhopal (Madhya Pradesh) in 1998. In 1984 he joined the faculty of Civil Engineering of the Polytechnic, where is presently a Senior Lecturer. He has wrote and author of more than 85 books including 14 textbooks of Civil. He is recipient of 4 National Awards from Government of India and 28 other prestigious awards. His research interests are in the field of Solid Waste Management and Technical Education.

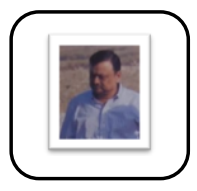

Dr. P.K. Ghosh received the Bachelor Degree in Civil Engineering and the Ph.D. in Environmental Engineering from Pt. Ravishankar Shukla University, Raipur, Chhattisgarh. At present he is Principal at Krishna Engineering College, Bhilai. He has author of more than 50 research papers especially on Environmental Engineering. His research interests are in the field of Environmental Engineering.

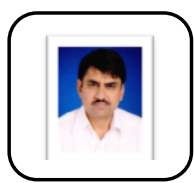

Dr. M.K. Gupta was born in Chhattisgarh and received his M.E. in Structure and then Ph.D. in Steel Structure from D.A.B. University, Indore (Madhya Pradesh). He is author of more than 48 research papers and articles. His research interests are in the field of Structural Engineering. At present he is Professor \& HOD (Civil) at Bhilai Institute of Technology, Durg.
Published By:

Blue Eyes Intelligence Engineering

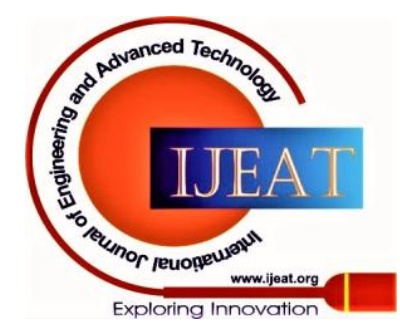

